\title{
Sporckovské burlesky v Kuksu: Spinckonarto (1727); Asterea, Tamerlan und Bajazet (1730); Romanische Lucretia 1732
}

\author{
Sporckian Burlescas in Kuks: Spinckonarto (1727); Asterea, \\ Tamerlan und Bajazet (1730); Romanische Lucretia 1732
}

Stanislav Bohadlo / bohadlo@jmc.cz

Hudební katedra, Univerzita Hradec Králové, CZ

\begin{abstract}
Thanks to daily records by Tobias Anthony Seeman, Count of Sporck's (1662-1738) Hofmeister in Kuks (Kuckus-Baade) on Elbe, NE Bohemia, we are able to reconstruct the new type of European music theatre outside of traditional centres. The biographic Spinckonarto and especially two not yet known performances in Kuks Asterea, Tamerlan und Bajazet and Romanische Lucrezia proof the existence of Teutschen musica bernesca - i.e. a burlesca type at Sporck's dominion even earlier than Heinrich Rademin's attempts in Vienna (1731), Felix Kurtz's activities in Prague (1733), or Antonio Denzio's rescue plans in Prague even later (1735). The Kuks burlescas result from coexistence of late commedia dell'arte, German Hauptaktionen and Hanswurstiadas, Italian opera seria with comic intermezzos and marionette theatre in both professional and non-professional modifications.
\end{abstract}

\section{Key words}

Burlesca; musica bernesca; Kuks; Franz Anton Graf von Sporck; Spinckonarto; Asterea, Tamerlan und Bajazet; Romanische Lucretia 
„Když se Italové pokusili přijít na pomoc opeře seria s něčím veselým." J. v. K. Bernardon, 1770

Kukské burlesky jsou výsledkem koexistence pozdní commedia dell'arte, německých hauptakcí a hanswurstiád, italské opery i loutkového divadla v profesionálních a amatérských modifikacích

\section{1727-1729}

Zprávy o neprofesionálních divadelních a hudebních produkcích v Kuksu začínají rokem 1727, kdy hrabě Sporck neodjel na zimu do Prahy, ale zůstal ve svém kukském zámečku. Dne 25. února dal podle Seemanových záznamů ${ }^{1}$ návštěvě z Hlohova (Glogau) zahrát přídavek (Nachspiel) Harlekins Hochzeit, patrně vlastními silami, protože v Kuksu nepobývala žádná herecká společnost, ale detaily a formu neznáme. Mohlo by se jednat o typ sólového výstupu prostoduchého sedláka Kiliana Brustflecka, jak ho dříve reprezentoval eggenberský dvorní blázen Johann Valentin Petzold (†1721), který hrával př́ídavky k loutkovým představením Sporckova Hofcomoedianta Antona Josepha Geisslera (†1723).

„25. 2. Die baron Larichin des Glogauer herrn landthauptmann graffen Kottolnitzki frau schwester mitfahren H. sohne und freyle tochter von Prag anhero kommen. Abents Ihnen ein nachspiel des Herlekins Hochzeit produziren lassen."

Devátého března, $\mathrm{v}$ den hraběcích narozenin, pak na jeho počest za přítomnosti augustiniánského loutnisty P. Amanda Roffelda OESA Disc. (Amandus a Nomine Jesu, 1684-1750), př́štího priora kláštera v Lysé nad Labem, nastudovali kukští Hofbedienten novou hru Spinckonarto (přesmyčka Antoni Sporck), ${ }^{2}$ která se podle Seemanových zápisků hraběti velmi líbila. Z hofmistrova dopisu Hanckemu z 13. března, jak uvádí Benedikt, ${ }^{3}$ se dovídáme o zbásněné komedii nějakého kukského básníka („vom Kukuser Poeten“) s celým názvem „Die glücklich und unzertrennliche Vermählung des tugendhafften Ritters Spickonarti“s áriemi, které se zpívaly s instrumentálním doprovodem nepochybně pod Seemanovým vedením od cembala. ${ }^{4}$

„Den 9ten dito. Nachmittag Ihro Exll. Dem Pfarer und Pater Amant vorkommen lassen, das Christl. Jahr mit den neuen Arien absingen lassen, abents Ihro Exll. Hofbediente. zu Ihro Exll. Ehr eine neue Comaedi Spinckonardo betitult producirt; welche Ihro Exll. Wohl gefallen."

1 NPÚ, knihovna hospitálu v Kuksu, Kalendářové deníky T. A. Seemana, ročníky 1728-1729, 1731-1735, 1737; Kalendářový deník T. A. Seemana, ročník 1727, rodinný archiv Sweerts-Sporck, Vídeň.

2 BACK, Ernst, 1937. Spinckonarto, eine Lebensbeschreibung Sporcks. In: Mitteilungen des Heimatmuseums Kukus a. E., 3, Kukus, s. 5-13.

3 BENEDIKT, Heinrich, 1923. Franz Anton Graf von Sporck (1662-1738). Zur Kultur der Barockzeit in Böhmen, Wien, s. 140.

4 Tamtéž. 
Jedná se snad o burleskní adaptaci životopisného tisku J. Müllera ze Schweidnitz z roku 1725 od neznámého autora pod pseudonymem Gustav Columbus Siegfried s titulem Reiner Spiegel Löblicher Eigenschafften, Eines Christlich- Recht- und Wahrheits-liebenden Herrens. ${ }^{5}$ Comoedi se opakovala 16., a hned po př́jezdu Antonia Bioniho (!) do Kuksu 23. března 1727 za jeho př́itomnosti. Následující den odvážel Bioni opis komedie (comoedi) Karlu Josephovi de Grossa do Vratislavi.

\begin{abstract}
„Den 23ten dito. Umb 11 uhr der Bioni von Prag allhier ankommen, abents Ihro Excellenz die comoedi von Spinckonardi in gegewarth des Bioni repetiren laßen.

Den 24ten. Frühe der Bioni nacher Breßlau abgereist, welchen ein manuscript von Herkomani und eine abschrifft von der comoedi vor dem herrn de Grossa mitgegeben worden."
\end{abstract}

Nevíme však, zda kukský Spinckonarto z roku 1727 v provedení dvorního služebnictva spíše inklinuje k hudební výbavě typu sporckovských písní, nebo k uplatnění italských árií. $\mathrm{V}$ prvním př́padě bychom s jistou odvahou mohli uvažovat o existenci sporckovské burlesky ještě dříve, než se ustavila tato německy hraná hudebně-divadelní forma s hudbou italských árií, což by bylo třeba ještě pramenně doložit.

K významným událostem kukského repertoáru patř́ F. A. Defrainova produkce Der undankbar Basiliscus z léta 1728, který lehkomyslností nezkušeného Hanswursta v převráceném světě přivedl Sporcka k úvaze, že viděné je účinnějšsi než jen slyšené, a proto „utrácím za komedie, abych vzdèlal, poučil a vyčistil nevédomou li̊zu“. ${ }^{6}$

Na počátku července 1729 už Seeman zaznamenal, že několik herců se zúčastnilo panského chytání parem u Stanovic. Byli to oni, kteří desátého pro hraběte a jeho hosty zahráli Comoedi von Mauritio römischen Burgermeister, aniž bychom byli schopni bližší identifikace.

„10. 7. Den 10.ten Wegen Regenwetter Ihro Excell. das Christliche Jahr in Ihren Zimmer singen und lesen lassen, die Comoedi von Mauritio römischen Burgermeister gewesen."

\title{
II. 1770
}

Přeskočme pro definici burlesky do roku 1770, do Vídně k oznámení v libretu „LA SERVA PADRONA / Die Dienerin eine Frau, oder die vier ungleichen Heurathen, Ein neues Lustspiel mit 17 von zweyen Abtheilungen in Wersen Arietten und Duetten, nebst einem Chorus, aus einem italiänischen Intermezzo gezogen. WIEN, gedruckt bey Joh. Thom. Edlen v. Trattnern, keiserl. Königl. Hofbuchdruckern und Buchhändlern. 1770“7

5 SIEGFRIED, Gustav Columbus, 1725. Reiner Spiegel Löblicher Eigenschafften, Eines Christlich- Recht- und Wahrheits-liebenden Herrens. Schweidnitz [online]. [cit. 15. záŕí 2016]. Dostupné z: http://resolver.sub.uni-goettingen.de/purl?PPN718317203.

6 BENEDIKT, s. 140.

7 KURZ, Joseph Felix von - PERGOLESI, Giovanni Battista. La serva padrona [libretto], Wien, 1770 
Joseph Felix von Kurz (1717-1784) pod zkratkou J. v. K. Bernardon popisuje v Avertissement k Die Dienerin einer Frau, oder die vier ungleichen Heurathen, že La serva Padrona byla jedním z prvních italských intermezz, „v němž se Italové pokusili přijít na pomoc opeře seria s něčím veselým“. Ze dvou aktérů byli tři, čtyři a nakonec Opera buffa G. B. Pergolesiho. Hudba je do této chvíle vysoko ceněná, uvádí, takže ji převzali a přetextovali i Francouzi. „Kdo by mě káral za to, že i mě napadlo převést toto intermezzo do mé mateřštiny?" Udělal to ostatně s úspěchem už v roce 1768 v Mainzu za př́tomosti kuřfiřta. Doplnil Uberta a Serpinu o tři další milostné dvojice. „Ve veselohře zazpívají herci a herečky 17 německých ariet a duetů vedle jednoho sboru. " jsou v libretu označeny jako „Aria. Nach welscher Musik“. Joseph Kurz tehdy očekával "oprávněnou" kritiku, ale dávno dobře věděl ze své zkušenosti a z působení svého otce v Kuksu, že burleska je v jazykově německém prostředí vyhledávaným typem hudebního divadla, což mělo vyústit v klasicistní singspiel.

Je nutné zdůraznit, že ve sporckovské hudební subkultuře se termín Aria objevoval zcela v souladu s typickou barokní koexistencí vysokého a populárního umění ve dvou zásadních významech. Jednak to byl útvar z dobře známých italských oper seria od př́jezdu Peruzzi-Denziovské operní společnosti z Benátek v srpnu 1724, a potom se Aria v synonymech Melodey a Lied používala v produkci tzv. sporckovských árií počínaje Bonreposkou (a Hubertskou) systematicky od roku 1721 (Bon-Repos Büchlein) ke zpěvu duchovních, popisných, oslavných, dialogických, čarodějnických, protijezuitských a protiprávnických písní, což vyvrcholilo edicemi těchto nápěvů (většinou odvozených z francouzských parforsních signálů) v tzv. Svídnickém kancionálu $(1725,26)$ a v Křsstanském roku $(1733,34) .{ }^{9}$

\section{1730}

Příběh barbarského dobyvatele ze 14 . století Tamerlana (Timura) se šiřil podle svědectví arabského rukopisu z let 1437-1443 od syrského autora Ahmad lbn ,Arabshah, sekretáře Sultána Ahmada z Bagdádu. V průběhu 16. století proslavil Timura v Evropě Christopher Marlowe svou hrou Tamburlaine (1590).

Tureckou barokní tématiku převzal i Giovanni Battista Andreini do své hry La Turca z roku 1611, která se provozovala po korunovačních slavnostech v roce 1628 také v Praze: La Turca comedia boscareccia, et maritima. Di Gio. Battista Andreini fiorentino. All. ecc.mo

[online]. [cit. 15. září 2016]. Dostupné z: Münchener Digitalisierungszentrum (MDZ) http://daten.digitale-sammlungen.de/bsb00056048/image_1.

8 Tamtéž, „In dem Lustspiel werden 17. deutsche Arietten und Duetten nebst einem Chorus von denen Acteurs und Actricinnen gesungen. “

9 BOHADLO, Stanislav, 2012. Sporckovské „árie“ jako obecná nota z Bon Repos a z Lázní Kuks. Duchouni, životopisné, oslavné, propagační, lovecké, časové, čarodějnické, protijezuitské, protiprávnické, kramářské, dialogické a jiné pisně na nápěvy Bon-Reposké, Hubertské, Zaječi, Holubi, Pfuj, Kalvárské, Řádu křriže aj. árií, pisni a melodii. 1. vyd. Ústí nad Orlicí, 199 s. ISBN 978-80-7405-183-8. 
mio s.re et padron collendissimo il s. Duca di Niuers dedicata..$^{10}$ Děj s hudebními postavami, režijními pokyny, veršovanými čísly (Suonatori; al suoni di trombe e tamburi; „Da le piume / Amorosetta / Sorgi, sorgi homai noc fretta; / Son'amante, / Che cantante / Di lodarti hò per costume; / Deh che fai? / Sorgi homai; / Scopri, scopri il viso adorno / Fà la notte un chiaro giorno") i s hudební tématikou ${ }^{11}$ se odehráva na španělském ostrově La Tabarca a vychází z konfliktu milenců v křestansko muslimském prostředí, protože ostrov je obsazen mohamedánským vojskem (Infiniti Turchi armati, Mehemet Turco).

Duch tureckého ohrožení katolické Evropy byl v roce 1713 stále ještě živou vzpomínkou, když 4. července Hochfürstliche Wirtenbergische Hof-Comoedianten společně s Hochfürstl. Mecklenburgischen Hof-Comoedianten hráli v pražském Sporckově divadle hauptakci Das Leben und Tod des grossen Welt-schröckenden ATTILAE. První doklad o ženské postavě Harlekýnky podává pražská divadelní cedule ke hře Tamerlan oder Der weibliche Arlequin z 18. 7. $1713 .{ }^{12} \mathrm{Z}$ cedule z 8. 1. $1719 \mathrm{k}$ hauptakci Der Fall deß grossen Attilae: Oder Han $\beta=$ Wurst der tyranisch und gro $\beta=$ prallende Soldat je patrná koexistence německého a italského divadla, kdy spolu na scéně stojí Hanswurst s Pantalonem (pravděpodobně Prehauser a Leinhaas). ${ }^{13}$ Činoherní představení najímaných Beruffs-Truppen v kukském Comoedien-Hausu probíhala v lázeňské sezóně (zpravidla od 1. srpna) od roku 1702. K 2. srpnu 1722 zaznamenal Benedikt ze sporckovské korespondence př́tomnost Markus Waldmannovy bandy v Kuksu v počtu 14 osob včetně Ferdinanda Ellensona a Ferdinanda Reichela, jak provedli komedii „von dem so genannten flagella Dei oder Grossen Weltbeherrscher Atilla " za př́tomnosti četných vratislavských hostí. ${ }^{14}$

Další turecké téma, tak důležité z životopisu Sporckova otce, císařského generála a turkobijce, se v Kuksu opět objevilo roku 1730, kdy už bylo (i napřristě) frekventovanou součástí evropského operního repertoáru, nejčastěji jako (Il gran) Tamerlano nebo Il Bajazette (Andreozzi, G., Bernasconi, A., Cocchi, G., Duni, E. R., Gasparini, F., Generali, P., Jommelli, N., Leo, L. (Imperatore de'Turchi), Marinelli, G., Westmoreland, Lord) či Der Bajazzo (Operetta, Czibulka, A.). ${ }^{15}$

10 ANDREINI, Giovanni Battista, 1611. La Turca [online]. [cit. 15. zář́i 2016]. Dostupné z: https://books. google.cz/books?id=mRr5CzN4uFYC\&hl=cs\&num=10\&source=gbs_slider_cls_metadata_2_mylibrary.

11 „Poeta: Hor senti come questo leuto è sonevole, e come cromaticamente armonizo; cedano pure à questo musico legno, il Sistro, il Taballo, e la Tibia antichi musicali strumenti; cedami pure Demedoco musico lodato da Orazio, Timote celevbrato da Aristotile, e cedami al fine il citaredo Traceo, che pietoso fece il dispietato Inferno, ben che havendo risguardo alla crudeltà di Candida dovrei cangiarmi in citerista da nenie al canto non candido cigno, ma al crocito nero corbo sembrando." Tamtéž, s. 16.

12 SCHERL, Adolf, 1999. Berufstheater in Prag 1680-1739. Wien, s. 33, 48 a 66.

13 BOHADLOVÁ, Kateřina, 2009. Astarto versus Atalanta. Heinrich Rademin, „Director Comicus“ (1674-1731), $v$ kontextu italskoněmecké divadelni dramaturgie počátku 18. století, diss. FF UK, Praha.

14 BENEDIKT, s. 126 a pozn. 362.

15 TOWERS, John, 1910. Dictionary-Catalog of Operas and Operettas, S Morgantown. 
Sporckovské burlesky v Kuksu: Spinckonarto (1727); Asterea, Tamerlan und Bajazet (1730) ...

\begin{tabular}{|c|c|}
\hline \multirow[t]{2}{*}{ Asteria } & Hasse, J. A. \\
\hline & Vinci, L. \\
\hline Asteria e Teseo & Guglielmi, P. C. \\
\hline \multirow[t]{6}{*}{ Tamerlan (El gran) de Persia } & Caballero, M. F. \\
\hline & Reichardt, J. F. \\
\hline & Winter, P. \\
\hline & Händel, G. F. \\
\hline & Keller, F (Chelleri) \\
\hline & Cocchi, G. / Peschetti \\
\hline (Bajazette) & Gasparini, F. 2 verze \\
\hline \multirow[t]{2}{*}{ Tamerlano } & Gini (Giai?), G. A. \\
\hline & Guglielmi, P. \\
\hline (Bajazette) & Leo, L. \\
\hline \multirow[t]{11}{*}{ Tamerlano } & Mayr, J. S. \\
\hline & Mysliweczek, J. \\
\hline & Paer, F. \\
\hline & Porpora, N. A. \\
\hline & Porta, G. \\
\hline & Sacchini, A. M. G. \\
\hline & Sapienza, A. \\
\hline & Scarlatti, A. \\
\hline & Scolari, A. \\
\hline & Tadolini, G. \\
\hline & Vivaldi, A. \\
\hline Il gran Tamerlano & Ziani, M. A. \\
\hline
\end{tabular}

Tab. 1 Přehled autorů dobových oper s tureckou tematikou.

Přítomnost vratislavského principála Felixe Kurtze (1668-1760), otce Josepha, v Kuksu v roce 1730 se dosud v literatuře neuvádí. Svou kariéru jako principál a Hanswurst začal v Brně (1725) a pak je jeho pohyb téměř rok za rokem dobře doložen. Ani Adolf Scherl a Bärbel Rudin v nejnovějším hesle ve slovníku Theater in Böhmen, Mähren und Schlesien (2013) nezmiňují jeho vyjednávání se Sporckem, jeho př́ijezd do Kuksu, ani zdejší repertoár.

Podle deníkového záznamu odpovídal hofmistr Seeman 15. února 1730, patrně příznivě, principálovi Felixu Kurtzovi do Vratislavi ohledně angažmá v nadcházející lázeňské sezóně v Kuksu.

„15. 2. Den 15.ten dito. nachmittag ich an dem Felix Kurtz, principal der compagnie commoedianten zu Breßlau eine antworth... geschrieben."

Dne 5. sprna přivezl do Kuksu svoji hereckou společnost s nabídkou a směli uskutečnit tři zkoušky, aby jejich výkon posoudili Ferdinand Reichel a Tobiáš Antonín Seeman.

„5. 8. Den 5.ten dito. Der comoediant Felix seine compagnie angetragen 3. proben machen zu dörffen, welcher von dem Ferdinand und mir beschieden worden." 
Seeman pak zkontroloval stav kukského divadla a dal posypat podlahu olšovým listím.

„8. 8. Den 8.ten dito. ... ich das comoediant-hauß wie es eingericht ist beschauet, solches außkehren, und mit erlen laub den boden bestreüen laßen."

Potom Kurtz i s celou společností zase odjel, ale 10. srpna už v lázních byli Sporckovi důvěrní přátelé Joseph i Franz de Grossa, kteří (patrně) za Seemanova doprovodu naslouchali zpěvu několika italských árií v podání Terezky Třešňákové, dcery vratislavského malíře, a Phylipiny de Grossa.

„10. 8. Den 10.dito nach der heyligen mes $\beta$ Ihro Excellenz mit dem alten und jungen herrn de Grossa geredt, nachmittag die Theresel bey mir in gegenwarth des alten und jungen herrn de Grossa nebst der freyle Phylipina etliche wellische arien gesungen."

Až 11. srpna se do Kuksu vrátil „comoediant Felix Kurtz a žádal o ubytování v jednom domě vedle Opern-Hausu, pročež bylo hornistovi Röllichovi nařízeno, aby ho vyklidil.“ Následující den přijeli herci (comoedianten).

„Den 11.ten ...umb 5. uhr der comoediant Felix hier ankommen, und in ein hauß neben opern hau $\beta$ zu wohnen verlanget, weßentwegen dem Leopold außzuziegen anbefohlen.

Den 12.ten dito. ... umb 19. uhr die comoedianten ankommen."

Dva dny zkoušeli a 13. srpna po př́ijezdu Třešňáka a dalších hostů z Vratislavi „začalo v 5 hodin první predstaveni (comoedi) o Astérii, Tamerlánovi a Bajazetovi, skončilo v 8 hodin. "Hrálo se pak denně kromě 16., 18. a 19. 8. až do 24. srpna.

„Den 13.ten nach der heyligen mes $\beta$ Ihro Excellenz mit dem alten und herrn de Grossa gesprochen, umb 2. uhr die fraw Scultetusin nebst ihren zwey jungstern töchtern und Trzessniack mahler von Breßlau hier ankommen, umb 5. uhr die erste comoedi von der Asterea, Tammerlan und Bajezet angefangen, umb 8. uhr geendiget worden."

Pátráme-li po společné předloze divadelních her a operních libret o Tamerlanovi, vede stopa k francouzské tragédii Nicolase Pradona Tamerlan ou la mort de Bajazet z roku 1676 s královským privilegiem Ludvíka XIV. ${ }^{16}$

V tomto duchu Domenico Pietropaolo a Mary Ann Parker upozorňují na operu Alessandra Scarlattiho z Fisherovy torontské sbírky Il Gran Tamerlano, s libretem Antonia Salviho podle této Pradonovy předlohy (Florencie 1706, Nella Villa di Pratolino). Libretista doplnil k Pradonově textu postavu Rossane (TAMERLANO, BAIAZER, ASTERIA, ANDRONICO, LEONE, ROSSANE, TAMUR) a doporučil studium svého vzoru.

16 PRADON, Nicolas, 1676. Tamerlan ou la mort de Bajazet. Paris [online]. [cit. 15. zář́i 2016]. Dostupné z: http://www.theatre-classique.fr/pages/programmes/edition.php?t=../documents/PRADON_MORTDEBAJAZET.xml. 
„Tutto il resto, che si rappresenta nel Drama parte e storico, parte e finto sul verisimile da Monsu Pradon di cui puo dirsi tutto il Drama; avendovi il solamente aggiunto il Personaggio di Rossane, e formatovi il secondo filo, per accomodarmi a gli'Attori, e per seguire il costume Italiano, solito introdur nella Scena almeno due Donne. Per ritrovare quello, chi vi e del mio, e necessario, che ti prenda la soddisfazione di leggere l'Autor Franzese, e doppo avere ammirata l'Opera di quello, compatire generosamente la mia."17

Další florentská opera Il TAMERLANO dramma per musica Agostina Piovene a Francesca Gaspariniho (který je autorem trojího zhudebnění), se hrála v roce 1719 opět s odlišnými postavami (TAMERLANO, BAIAZER, ASTERIA, IRENE, ANDRONICO, LEONE, ZAIDA), přestože se opět odvolává na Pradonovu předlohu. U Körnerových dědiců v Lipsku vyšly ještě v roce 1723 Gespräche in dem Reiche derer Todten ... zwischen dem weltberühmten großen Tamerlan, kaysern derer Tartaren un Mogols, auch Herrns fast von gantz Asien, und dem grausamen Attila, König derer Hunnen ... ${ }^{18}$, kde se pojednávaly zcela vzácné události, velké činy, krvavé dílo, násilné skutky, jakož i pád tureckého císaře Bagazetha, jeho zajetí, krutý rozsudek a jeho ubohá smrt. Vzhledem k tomu, že nemáme k dispozici kukské (vratislavské?) libreto ani hudebniny, nelze zatím rozhodnout výsledný tvar a autorství. Zcela jistě to v Kuksu nebyla italská opera.

Jana Perutková zmiňuje ve své míčovské monografii překladatele questenberských libret, herce Andrease Weidnera. Ten ,působil jako herec a později principál v mnoha evropských městech. V r. 1732 napsal ve Vídni libreto k bernesce nazvané Bajazeth und Tamerlan, uvedené $v$ divadle U Korutanské brány“. ${ }^{19}$ Kukský Tamerlan je však o dva roky starší, přičemž Weidner se opíral o formu Heinricha Rademina. ${ }^{20}$ Přesto můžeme s odkazem na přítomnost italsky zpívajících pěvkyň a německy hrající společnosti o kukské burlesce uvažovat.

Ze závěru této kukské sezóny máme ještě zprávu o hře Maximiliano, provedené profesionální divadelní společností.

„1730 10. 9.; Den 10.ten vor der heyligen mes $\beta$ Ihro Excellenz ein und anders wieder anbefohlen, nach der heyligen mes $\beta$ im saal in gegenwarth des baron Turek und etlichen comoedianten einen langen disscur von ihren sistemat. geführt alß dann zum Stein und Abischbrünel gefahren, nach den esßen geruhet, umb 5 uhr die comoedi von Maximilano anfangen."

17 PIETROPAOLO, Domenico - PARKER Mary Ann, 2011. The Baroque Libretto: Italian Operas and Oratorios in the Thomas Fisher Library at the University of Toronto. Toronto, s. 150 [online]. [cit. 15. září 2016]. Dostupné z: https://books.google.cz/books?id=H-HMDvZjk_UC\&pg=PA150\&lpg=PA150\&dq=Pradon+Tamerlan\&source=bl\&cots=ua_DeTMNkt\&sig=WVZOXwfIc-QnR1ZGJTWSduc5zrU\&hl=cs\&sa=X\&ved=0ahUKEwiF4J_03-zJAhUJWCwKHYcND60Q6AEIUDAI\#v=onepage\&q=Pradon\%20Tamerlan\&f=false.

18 ANONYM, 1723. Gespräche in dem Reiche derer Todten. Leipzig [online]. [cit. 15. září 2016]. Dostupné z: http://reader.digitale-sammlungen.de/de/fs1/object/display/bsb11021581_00002.html.

19 PERUTKOVÁ, Jana, 2011. František Antonín Míca ve službách hraběte Questenberga a italská opera v Jaroměřrcích. Praha, s. 87.

20 BOHADLOVÁ, op. cit., s. 87. 


\title{
IV. 1731
}

Následujícího roku (1731) hrabě Sporck Felixe Kurtze nejprve odmítl, ale po opětovné veršované žádosti směl principál se svou trupou za poloviční gáži a dva sudy piva do Kuksu přijet hrát na dva měsíce v červenci a srpnu. Spolurozhodovali o tom i Seeman, Ferdinand Reichel a sekretář Scheffknecht.

\begin{abstract}
„13. 4. Den 13ten dito ...
Item ich dem Felix principal nacher Breßlau geschrieben und keine sonderliche hoffnung zu annehmung einer compagnie comaedianten vor heyer anzunehmen gegeben, in deme zur zeit noch nicht daran gedacht wirdt.

16. Den 1ten Junij ... Der Felix comaediant Ihro Excellenz inständig umb den consens gebetten, umb diesen sommer allhier agiren zu dörffen, worauf aber noch keine resolution erfolget.

Den 3ten Junij nach der heiligen mes $\beta$, nach gemachter überlegung und einrathung ein und anders bediendten resolvirt dem Felix principal mit seiner compagnie auff zwey monath nemb durch den Julij und August monath (wann nichts verhinderliches inzwischen kombt) anzunehmen, welche resolution ich in gegenwarth des Ferdinands ihme Felix hinterbracht.

14. 7. Den 14ten dito frühe umb 7 uhr Ihro Excellenz die Bresßlauer postbrieffe vorgenommen, alß dann dem secretarij, mir und dem Ferdinand anbefohlen dem Felix principalen die resolution auff sein gestrig in versen eingegebenes memorial zu hinterbringen, daß weilen Ihro Excellenz wegen dero unpäßligkeit nicht in die comaedi gehen und agiren laßen können, alßo wann er die wochen die helffte gagé nebst zwey emer bier vor ihm und dem Bellerodi nehmen wolten. Ihro Excellenz ihnen solches geben wolten, sie mögen agiren oder nicht. Abents dem verwalter angedeütet, das er dem Felix principal auff die verstrichene zwey wochen interim $60 \mathrm{R}$ auszahlen solle."
\end{abstract}

V létě skutečně v Kuksu i za těchto podmínek Kurtz hrál. Jeho trupu tvořila manželka Edmunda a sedm jejich dětí včetně již zmiňovaného Josepha, tehdy čtrnáctiletého. Skupinu dále tvořili herci Ch. Schulze, F. A. Nuth, F. J. J. Müller, Hirscher a Rock (J. A. Bruck). Uvedli zde v září také barokní hauptakci Doctor Faust.

„1731 8. 9.; Den 8ten dito umb 9 uhr die heilige mes $\beta$ celebritrt worden, alß dann Ihro Excellenz [Franz Anton von Sporck] zu St. Antonj gefahren. Ich [Tobias Anton Seeman] eine fuhr auff morgen und die übrige fuhren auff künftigen freytag zur abreiße bestellet. Nachmittag die comaedi on doctor Faust geweßen.

Den 9 ten dito Nach der heiligen mesß Ihro Excellenz spazierengefahren, nachmittag in die comaedi."

Během svého několikaměsíčního vídeňského pobytu v roce 1727 viděl Sporck přímo z Questenbergovy lóže představení Doctor Faust nejméně dvakrát, ${ }^{21}$ avšak provenienční identifikace schází.

21 BOHADLO, Stanislav, 2011. Questenberg a Sporck - oddělené a nezávislé barokní hudební subkultury na Moravě a v Čechách? Musicologica brunensia. 46 (1-2), s. 15-34. 
„1727 6. 7.; Den 6ten dito. ... dann Ihro Excellenz in die comoedi gefahren, in welcher der doctor Faust gespielt worden."

\section{1732}

V roce 1732 nás čeká v Kuksu další repertoárové překvapení. Jednak tu měli hraběcí poddaní nastudovat Das Spiel vom heiligen Nepomuk, což mohlo úzce souviset se sérií libret Heinricha Rademina od roku 1727 pro svatojánská oratoria Georga Reuttera, vídeňského dvorního varhaníka a ředitele kůru u sv. Štěpána. ${ }^{22}$

Sporckovo služebnictvo pod vedením Sporckova komorníka Leonarda Hellera nastudovalo na 17. února premiéru hry Die Romanische Lucretia, resp. Tarquinius und Lucretia, jak se titul v Seemanově deníku objevil ještě jednou o týden později i s poznámkou o jiných nových hercích, jmenovitě páže Hanßel, Philip, Simplicius, Wotawa, Überle, Springer a další. Toto kukské představení dosavadní literatura také nezná. Není jasné, zda červnové představení ve špitále s následným ohňostrojem bylo identické.

„Den 17ten dito [Februarii 1732] Abents der cammerdiener mit etwelchen bediendten vor Ihr Excellenz zum unterhalt eine comaedi, die Romanische Lucretia betitult, auff den saal produciret.

Den 24ten dito Umb 6 uhr abents die comaedi von Tarq. und Lucretia von andern und neüen acteurs, alß dann Hanßel page, Plilip, Simplicio, Wotawa, Überle, Springer und andern noch einmahl repetirt worden, welche solche comaedi zum erstenmahl agirt und noch zimblich guth gemacht."

Den 9ten dito [Junii 1732] umb 6 uhr abents ins spithal zu der comaedi gefahren, welche fast gegen 11 uhr getauert. Nach der comaedi etliche raqueten, feüerröder und einen schwarm gelaßen worden.

Autorské ani hudební informace $\mathrm{k}$ tomuto titulu zatím nemáme, ale je nápadné v souvislosti s Kurtzovou zálibou v divadelní burlesce, „multimediální podívané“ podle Scherla, a se Sporckovými styky s Heinrichem Rademinem, že se o rok dříve objevuje v tištěném libretu s Rademinovým jménem ve Vídni a s označením Teutschen Musica bernesca. ${ }^{23}$ Otto G. Schindler dílo považuje za travestii hamburské opery Die kleinmütige Selbstmörderin Lucretia od Bertholda Feinda s hudbou Reinharda Keisera už z roku 1705, kde roli Tarquinia Superba hrál Hanswurst a Bruta Scapin. ${ }^{24}$ Hudební komika „durch

22 1. Der liegend-obsiegende Held, 1726, 2. Schweigendes ORACULUM oder die wohlredende Verschwiegenheit des Glorreichen Martyrers, 1727, 3. JOANNES IN EODEM, das ist Der im Leben und Todt unveränderlich=beständige Liebhaber Gottes und der Kirchen Heiliger JOANNES von NEPOMUCK, 1728, 4. Canticum Novum, 1730. Srv. RUDIN, Bärbel, SCHERL, Adolf, 2013. Heinrich Rademin, heslo In: Theater in Böhmen, Mähren und Schlesien. Von den Anfängen biszum Ausgang des 18. Jahrhundert, Wien, s. 542-543.

23 Die Römische Lucretia. Auf dem von Ihro Röm. Kayserl. und königl. Cathol. Majestät privilegierten Theatro in Wienn Im Jahr 1731 In einer sogenannten Teutschen Musica bernesca Vorgestellet Von inbenannten Persohnen Aufgesetzt von Rademin, Wienn / gedruckt bey Andreas Heyinger / Universitäts-Buchdruckern, Wien Bibl. A 140893.

24 SCHINDLER, Otto G., 2013. Heinrich Rademin. In Österreichische Musik-Lexikon (ÖML) [online]. [cit. 15. září 2016]. Dostupné z: http://www.musiklexikon.ac.at/ml/musik_R/Rademin_Heinrich.xml [2013/07/22]; „Noch 1760 wurde dieses Stück bei der Theatertruppe des Johannes Lind als eine „Opera-Comica oder Musica 
und durch en ridicule " inscenaci prosadila i na nově zřízenou scénu v Ballhausu u vídeňských františkánů. Podobně je i osecká Burlesca per il Carnevale na latinský text z roku 1732 dokladem šíření nového komického žánru v téže době i v klášterním kontextu. ${ }^{25}$ $\mathrm{V}$ červenci také nastudovalo Sporckovo služebnictvo hru Von Experto und der Innocentia, kterou ocenili hraběcí hosté Johann Joseph von Sporck, Maria Anna von Sporck, Maria Anna Apollonia von Finecke, Thaddäus Franz Obytecký z Obytec, Schmidel von Schmiden, Charlotta von Desfours a N. Lamotte de Frintropp. Ani tentokrát nemáme $\mathrm{k}$ dispozici detaily.

„1732; Den 6ten dito [Juli]vormittag der graff Joseph von Sporck, seine gemahlin, freyle Fineckin und baron Obitetzky nacher Schurtz gefahren, den hohen ambt und der predigt beygewohnet. Nachmittag Ihro Excellenz bediendte die comaedi von Experto und die Innocentia gemacht, welche denen herrschafften sehr contentiret. Nachmittag der baron Schmidel mit siner gemahlin, wie auch die graffin de Fourin mit Ihrer schwester der freyle von Lamot hier ankommen."

\section{1735}

V roce 1735 hrál Felix Kurtz se svou společností za účasti biskupa Rudolfa von Sporck v Kuksu 10. srpna odpoledne, jednalo se o hru „o anglickém říšsém kancléri Thomasu Morovi“. 18. srpna přijeli do Kuksu jezuité včetně žireckého superiora Pichlera a Matthiase Antona Koniáše, aby došlo k usmíření. „... odpoledne všichni shlédli nové divadlo (comaedi), které se všem velice líbilo. "Je možné, že to bylo aktualizované představení duchovní tragédie z roku 1727 z Kuksu, či spíše (burleskní?) parafráze Bioniho opery Die Wagschale der Englischen Gerechtigkeit oder Thomas Morus uvedené v Kuksu roku 1730. ${ }^{26}$

„1735 10. 8. Den 10.ten dito. Nachmittag umb 4 uhr der Felix Kurtz, principal der commedianten, die erste comadi angefangen, welche sich umb 7 uhr geendiget. Nach der comadi der bischoff sich bey Ihro Excellenz beurlaubet.

Den 11.ten dito. ... nachmittag der comadi beygewohnt, welche von dem englischen reichs-cantzler Thomas Morus producirt worden.

Den 12.ten dito. Nachmittag Ihro Excellenz in Maliewaldtel in beyseyn einiger breßlauer und der comedianten ein thänel forcieren laßen, bey welcher perforsjagt la mort gemacht und das weydmesßer außgetheilt worden."

\footnotetext{
Bernesca von dem berühmten Rademin, gewesenen Liebling weyl. Kaisers Caroli VI. " angekündigt. Rademin wurde so auch zu einem Mitbegründer des Wiener Singspiels (Komödienarie).“ FLAHERTY, Gloria, 1978. Opera in the Development of German Critical Thought, Princeton, s. 307 rekapituluje, že „Rober Haas points out that Feind's text served as the model for Rademin's Römische Lucretia, Musica bernesca (1731)“, ,Wiedener deutsche Parodieopern um 1730', s. 205.

25 TROJAN, Jan, 2013. Burlesca per il Carnevale [heslo]. In Theater in Böhmen, Mähren und Schlesien. Von den Anfängen biszum Ausgang des 18. Jahrhundert, Wien, s. 90.

26 BENEDIKT, op. cit., s. 141.
} 
Představení se opakovalo ještě 14 . a 15. srpna. Kurtz zde měl v této sezóně uvádět i balety. ${ }^{27}$

Pak následovala „nová komedie“ bez bližší konkretizace se třemi reprízami do 1. září a na jevišti v hospitále pokračovala jezuitská kázání a demonstrativní usmíření s jezuity s Te Deum Laudamus v kostele Nejsvětější Trojice.

„Den 18.ten dito. Zu mittag der pater Pichler, missionarius, mit seiner gesellschafft von Königgratz ankommen. Zu mittag alle bey der freyle [Maria Anna Apollonia von Finecke] gespeißet. Nachmittag alle bey Ihro Excellenz geweßen und nachmittag einer neüen comædi beygewohnt, welche ihnen alle sehr wohl gefallen, alß dann alle in das spithal abents eingezogen.

Den 26.ten dito. Hat der pater Koniasch nachmittag die versöhnungspredigt von der liebe des nechsten gehalten, wo auch der pater superior von Ihro Excellenz gnädigen herrn in obern gang seine offentliche abbitt gethan. Ihro Excellenz auch nicht allein alles von hertzen verziehen, sondern auch allezeit ein gutter nachbar zu seyn und zu verblieben versprochen haben, über welchem christlichen actum jedermänniglich aufferbauet worden.

Den 28.ten dito. Vormittag Ihro Excellenz im spithal beym gottesdienst geweßen, nachmittag wieder der predigt, so der pater Pichler gehalten, dann den Te Deum laudamus und benediction beygewohnt."

Když pražské gubernium vsadilo na návrh pěvkyně a věřitelky Margarety Perriniové impresária Antonia Denzia 17. srpna 1734 do „arresto della Città Nuova“, netušil, že bude strádat v kobce jako zločinec přes sedm měsíců a že ho nakonec vysvobodí příslib, že je připraven bavit Pražáky ve Sporckově divadle s novými italskými herci, tanečnicemi a zpěváky s novou formou tzv. operettou s baletem a duety. Nabízel vlastně módní burlesku a po 31. březnu 1735 vydechl konečně na svobodě. Ale svůj plán či slib nakonec neuskutečnil, i když v Praze pobýval až do roku $1736 .{ }^{28}$

Závěrem lze konstatovat, že životopisný Spinckonarto a zejména dvě dosud neznámá kukská představení Asterea, Tamerlan und Bajazet a Romanische Lucrezia dokládají existenci Teutschen musica bernesca - čili burlesku v Kuksu dříve, než se Rademinovou zásluhou objevila ve Vídni (1731), Felix Kurtzovým přičiněním v Praze (1733) či v Denziových pražských záchranných plánech ještě mnohem později (1735).

\section{Bibliography}

\section{Sources and literature}

ANDREINI, Giovanni Battista, 1611. La Turca [online]. [cit. 15. září 2016]. Dostupné z: https:// books.google.cz/books?id=mRr5CzN4uFYC\&hl=cs\&num=10\&source=gbs_slider_cls_metadata_2_mylibrary.

ANONYM, 1723. Gespräche in dem Reiche derer Todten. Leipzig [online]. [cit. 15. září 2016]. Dostupné z: http://reader.digitale-sammlungen.de/de/fs1/object/display/bsb11021581_00002.html.

27 Lexikon zur deutschen Musik-Kultur, Bd 1, München 2000, sl. 1469.

28 NOVOTNÝ, Antonín, 1947. Z Prahy doznívajicího baroka 1730-1740. Praha, s. 220-228. 
BACK, Ernst, 1937. Spinckonarto, eine Lebensbeschreibung Sporcks. In: Mitteilungen des Heimatmuseums Kukus a. E., 3, Kukus, s. 5-13.

BENEDIKT, Heinrich, 1923. Franz Anton Graf von Sporck (1662-1738). Zur Kultur der Barockzeit in Böhmen, Wien, s. 140.

BOHADLO, Stanislav, 2011. Questenberg a Sporck - oddělené a nezávislé barokní hudební subkultury na Moravě a v Čechách? Musicologica brunensia. 46(1-2), s. 15-34.

BOHADLO, Stanislav, 2012. Sporckovské "árie“ jako obecná nota z Bon Repos a z Lázni Kuks. Duchovni, životopisné, oslavné, propagačni, lovecké, časové, čarodějnické, protijezuitské, protiprávnické, kramářské, dialogické a jiné pisně na nápěvy Bon-Reposké, Hubertské, Zaječi, Holubi, Pfuj, Kalvárské, Řádu křiže aj. árii, pisni a melodii. 1. vyd. Ústí nad Orlicí, 199 s. ISBN 978-80-7405-183-8.

BOHADLOVÁ, Kateřina, 2009. Astarto versus Atalanta. Heinrich Rademin, „Director Comicus“(16741731), v kontextu italskoněmecké divadelni dramaturgie počátku 18. století, diss. FF UK, Praha.

Der liegend-obsiegende Held, 1726, 2. Schweigendes ORACULUM oder die wohlredende Verschwiegenheit des Glorreichen Martyrers, 1727, 3. JOANNES IN EODEM, das ist Der im Leben und Todt unveränderlich=beständige Liebhaber Gottes und der Kirchen Heiliger JOANNES von NEPOMUCK, 1728, 4. Canticum Novum, 1730.

Die Römische Lucretia. Auf dem von Ihro Röm. Kayserl. und königl. Cathol. Majestät privilegierten Theatro in Wienn Im Jahr 1731 In einer sogenannten Teutschen Musica bernesca Vorgestellet Von inbenannten Persohnen Aufgesetzt von Rademin, Wienn / gedruckt bey Andreas Heyinger / Universitäts-Buchdruckern, Wien Bibl. A 140893.

KURZ, Joseph Felix von - PERGOLESI, Giovanni Battista. La serva padrona [libretto], Wien, 1770 [online]. [cit. 15. záŕí 2016]. Dostupné z: Münchener Digitalisierungszentrum (MDZ) http:// daten.digitale-sammlungen.de/bsb00056048/image_1.

Lexikon zur deutschen Musik-Kultur, Bd 1, München, 2000, sl. 1469.

NOVOTNÝ, Antonín, 1947. Z Prahy doznívajícího baroka 1730-1740. Praha.

NPÚ, knihovna hospitálu v Kuksu, Kalendářové deníky T. A. Seemana, ročníky 1728-1729, 17311735, 1737; Kalendářový deník T. A. Seemana, ročník 1727, rodinný archiv Sweerts-Sporck, Vídeň.

PERUTKOVÁ, Jana, 2011. František Antonín Míca ve službách hraběte Questenberga a italská opera v Jaroměricich. Praha.

PIETROPAOLO, Domenico - PARKER Mary Ann, 2011. The Baroque Libretto: Italian Operas and Oratorios in the Thomas Fisher Library at the University of Toronto. Toronto, s. 150 [online]. [cit. 15. září 2016]. Dostupné z: https://books.google.cz/books?id=H-HMDvZjk_UC\&pg=PA150\&lpg=PA150\&dq=Pradon+Tamerlan\&source=bl\&ots=ua_DeTMNkt\&sig=WVZOXwfIc-QnR1ZGJTWSduc5zrU\&hl=cs\&sa=X\&ved=0ahUKEwiF4J_03-zJAhUJWCwKHYcND60Q6AEIUDAI\#v= o- $^{-}$ nepage\&q=Pradon\%20Tamerlan\&f=false

PRADON, Nicolas, 1676. Tamerlan ou la mort de Bajazet. Paris [online]. [cit. 15. záŕí 2016]. Dostupné z: http://www.theatre-classique.fr/pages/programmes/edition.php?t=../documents/ PRADON_MORTDEBAJAZET.xml.

RUDIN, Bärbel - SCHERL, Adolf, 2013. Heinrich Rademin [heslo]. In Theater in Böhmen, Mähren und Schlesien. Von den Anfängen biszum Ausgang des 18. Jahrhundert, Wien, s. 542-543.

SCHERL, Adolf, 1999. Berufstheater in Prag 1680-1739. Wien, s. 33, 48 a 66.

SCHINDLER, Otto G., 2013. Heinrich Rademin. In Österreichische Musik-Lexikon (ÖML) [online]. [cit. 15. září 2016]. Dostupné z: http://www.musiklexikon.ac.at/ml/musik_R/Rademin_Heinrich.xml [2013/07/22].

FLAHERTY, Gloria, 1978. Opera in the Development of German Critical Thought, Princeton.

SIEGFRIED, Gustav Columbus, 1725. Reiner Spiegel Löblicher Eigenschafften, Eines Christlich- Recht- 
und Wahrheits-liebenden Herrens. Schweidnitz [online]. [cit. 15. září 2016]. Dostupné z: http:// resolver.sub.uni-goettingen.de/purl?PPN718317203.

TOWERS, John, 1910. Dictionary-Catalog of Operas and Operettas, S Morgantown.

TROJAN, Jan, 2013. Burlesca per il Carnevale [heslo]. In Theater in Böhmen, Mähren und Schlesien. Von den Anfängen bis zum Ausgang des 18. Jahrhundert, Wien, s. 90. 